\title{
USING OF SOLAR ENERGY \\ FOR THE OPERATION OF A COOLING SYSTEM FOR THE HYDROPONIC IN THE GREENHOUSES
}

\author{
Amina, A. Soliman ${ }^{1}$; M. F. Abdel-Salam²; Ahmed, M. Kassamªnd \\ M. M. Mostafa ${ }^{2}$
}

ABSTRACT

This research aims to study the effect of using the cooling and ventilation system on the production and quality of lettuce and mint crops in autumn and winter season. Two poly-greenhouse models were constructed at the Agricultural Engineering Research Institute (AEnRI), Al-Giza Governorate, Egypt (Latitude of $30.02^{\circ}$ and longitude of $31.13^{\circ}$ ). One of them was equipped with photovoltaic $(P V)$ system to feed electrical load of greenhouse as cooling and ventilation control system (treatment) to control, the maximum and minimum temperature to control the interior climate and the other was a traditional greenhouse (control). The plants were planted in a greenhouse under a hydroponic system. Results of the experimental work shows that the specific approach of cooling and mechanical ventilation for lettuce and mint crop production enhances the rate of growth and increasing the fresh lettuce and mint yield by $52.88 \%$ and $49.91 \%$, respectively comparing with control greenhouse.

Key words: Greenhouse, Evaporative cooling, Fan and pad cooling, Ventilation, Relative humidity, PV system, NFT system, crops lettuce and mint.

\section{INTRODUCTION}

The greenhouse techniques are considered among the most important elements of agriculture intensification. Due to the

dramatic increase of Egypt population and its limited agricultural area, vertical- expansion of agricultural production is necessary. The main purpose of a greenhouse is to improve the environmental conditions in which plants are grown. Greenhouses are usually equipped with some environmental modification devices such as cooling, ventilation and heating systems. Ventilation can remove excess heat, increase air mixing, and reduce temperature stratification in the greenhouse (Kumar, et al 2009).

1. Agricultural Engineering Research Institute, Agric. Res. Center, Dokki, Giza 2. Agric. Eng. Dept., Faculty of Agriculture, Ain Shams University, Cairo, Egypt 
During autumn, in Egypt, ventilation alone is not enough to maintain optimum interior temperature. Therefore, water evaporative cooling systems and fans are usually used to reduce the interior air temperature to an acceptable level. The cooling of these systems is commonly accomplished by using an electrically driven fan, pad (Marcel., et al 2006). The function of the fan and pad is to prevent greenhouse overheating and cool the plants during hot weather. Whereas, the function of the shading technique is to reduce the amount of solar thermal radiation and penetrates only the sunlight that is necessary for growing of plants. Therefore, to electrify the previously mentioned cooling equipment's that are used in remote area greenhouses it is necessary to use a well-designed stand-alone photovoltaic (PV) system.

Generally, Climate control is of great importance for greenhouse production in order to achieve high yield and good quality crops that meet the demands of consumers, as well as for economical production. Temperature and relative humidity $(\mathrm{RH})$ are two basic climatic parameters usually controlled by heating and ventilation equipment. It is more difficult to control $\mathrm{RH}$ than temperature because relative humidity not only relies on air exchange from the infiltration and ventilation, but also related to evaporation from growing media and transpiration of the plants. (Gao 2012).

A greenhouse is a framed structure covered with a transparent material in which the environment can be artificially regulated to optimize the growth of plants. Temperature and humidity are the pre-dominant factors that govern the microclimate inside a greenhouse (Santosh et al., 2017). In the subtropical and tropical countries, the climate remains hot and humid for major part of a year. High temperature is detrimental for the cultivation of high value target crops like lettuce (Lactuca Sativa) which thrive at a temperature between 17 and $24{ }^{\circ} \mathrm{C}$ with the maximum viable temperature being $28{ }^{\circ} \mathrm{C}$ (Abu-Hamdeh and Almitani, 2016). This can be one of the primary reasons that most of the leading lettuce producing regions (major part of United States of America, Spain, Italy and parts of China) are not located in the hot and humid subtropical and tropical parts of the world (FAOSTAT, 2014).

Therefore, the main objective of this paper is to introduce a proposed greenhouse cooling system, which uses a stand-alone PV system to feed 
the electrical load of the greenhouse. At the same time, it introduces the complete sizing procedure of the greenhouse PV system. This will enable Egypt to face the increase in foods, in addition to increase the yield product per unit area of land. The present research is aimed to develop, construct, and test an experimental greenhouse that will be equipped with cooling and ventilation control system to maintain optimum growing environment for Lettuce and mint growth during autumn season through the following specific objective:-

1- Connecting the greenhouse to an adequate cooling system.

2- Supplying the designed system with environmental instruments to control the interior climate for plant growth under environmentally controlled high-yield conditions as well as offering an opportunity to reduce the electrical energy consumption.

3- Investigating the effect of adequate mechanical ventilation to adjust the relative humidity of air inside the constructed greenhouse.

4- Comparing the productivity of the designed system with a traditional greenhouse that has the same shape, dimensions, cover, and orientation with natural ventilation.

5- Evaluate the costs of the cooling system by using full PV electricity production.

\section{MATERAIL AND METHODS}

\section{Description of the greenhouses:}

Two identical gable-even-span greenhouses were designed, constructed and installed on at the Agricultural Engineering Research Institute (AEnRI) , Al-Giza Governorate, Egypt (Latitude of 30.02 ${ }^{\circ}$ and longitude of $31.13^{\circ}$ )as shown in Fig.(1) . The experiments were carried out during the autumn months from September to October (2018/2019). Each greenhouse was $4.0 \mathrm{~m}$ long and $2.0 \mathrm{~m}$ wide and 2.8 heights, with a net floor surface area of $8 \mathrm{~m}^{2}$. The structural frame of the greenhouse is made of the water - galvanized pipes 0.5 inch diameter. The rafter length of the gable of greenhouse is $1.25 \mathrm{~m}$ the gable height is $0.8 \mathrm{~m}$, and height of each side wall is $2 \mathrm{~m}$. The rafters are tilted at $30^{\circ}$, to minimize the side effects of wind load on the roof of greenhouse and to reduce the intensity of solar radiation during summer months. At the same time it may maximize the solar radiation flux incident on the inclined roof of the greenhouse during winter months. The greenhouse frame was covered using $0.2 \mathrm{~mm}$ 
thickness polyethylene sheet. To increase and maintain the durability of structural frame and polyethylene cover, twenty-five tensile galvanized wires $(0.16 \mathrm{~cm}$ diameter $)$ were tied and fixed throughout the rafters, curvatures, and vertical pipes in each side of the greenhouse frame. The experimental greenhouses were orientated to North-South direction. This direction of orientation was found to be the best direction for maximizing solar energy available inside the greenhouse (Arbel et al., 2003).

The first greenhouse was used to study and test the effect of cooling the interior climate and mechanical ventilation on the growth and production of Lettuce and mint crop. This system is responsible for reducing the air temperature inside the greenhouse that affects the greenhouse environment and consequently the growing of cultivated plants. The proposed cooling system consists mainly, of four components. These components are aluminum pad, cool air fan, pump and sump. The pad-fan system requires sufficient makeup water to replenish the water evaporated from the pad into the incoming air. When large quantities of air are pulled through the evaporative cooling pads that are saturated with water, a substantial cooling effect is realized due to the evaporation of that water. This makeup water is supplied by a reliable pump, which pumps the water from sump and delivers it to the pad. Therefore, the pad can be kept wetly during the cooling system operation.

This cooling technique can insure a reduction of greenhouse interior temperature to about $10-25^{\circ} \mathrm{C}$. Evaporative cooling pad was installed in one end of the greenhouse with $2 \mathrm{~m}$ length; fully covered excluding side door, $0.5 \mathrm{~m}$ height and $0.12 \mathrm{~m}$ thickness. Pump and sump Power $55 \mathrm{~W}$, Source of power $3000 \mathrm{~L} / \mathrm{h}$. A $40 \mathrm{~cm}$ diameter fan with window $(50$ X 50 $\mathrm{cm})$. It plant by using NFT system it pushed by 75 Watt submersible pump. The seedling plant in plastic cups $7 \mathrm{~cm}$ diameters, it full by perlite and peat moos. Used deep water culture and its dimension $1.5 \mathrm{~m}$ $* 1 \mathrm{~m} * 0.5 \mathrm{~m} .1 \mathrm{~m}^{2}$ contained 24 plants. The roots of plants Submersible in water tank.

PV system consists of three modules 265Weach with Charge Controller 12/24 V, 16 A Load, 30 A Charge Current and the Battery (12 volts, 170 Amp.h) and inverter (12/24 V DC - $1500 \mathrm{~V} \mathrm{AC})$. 


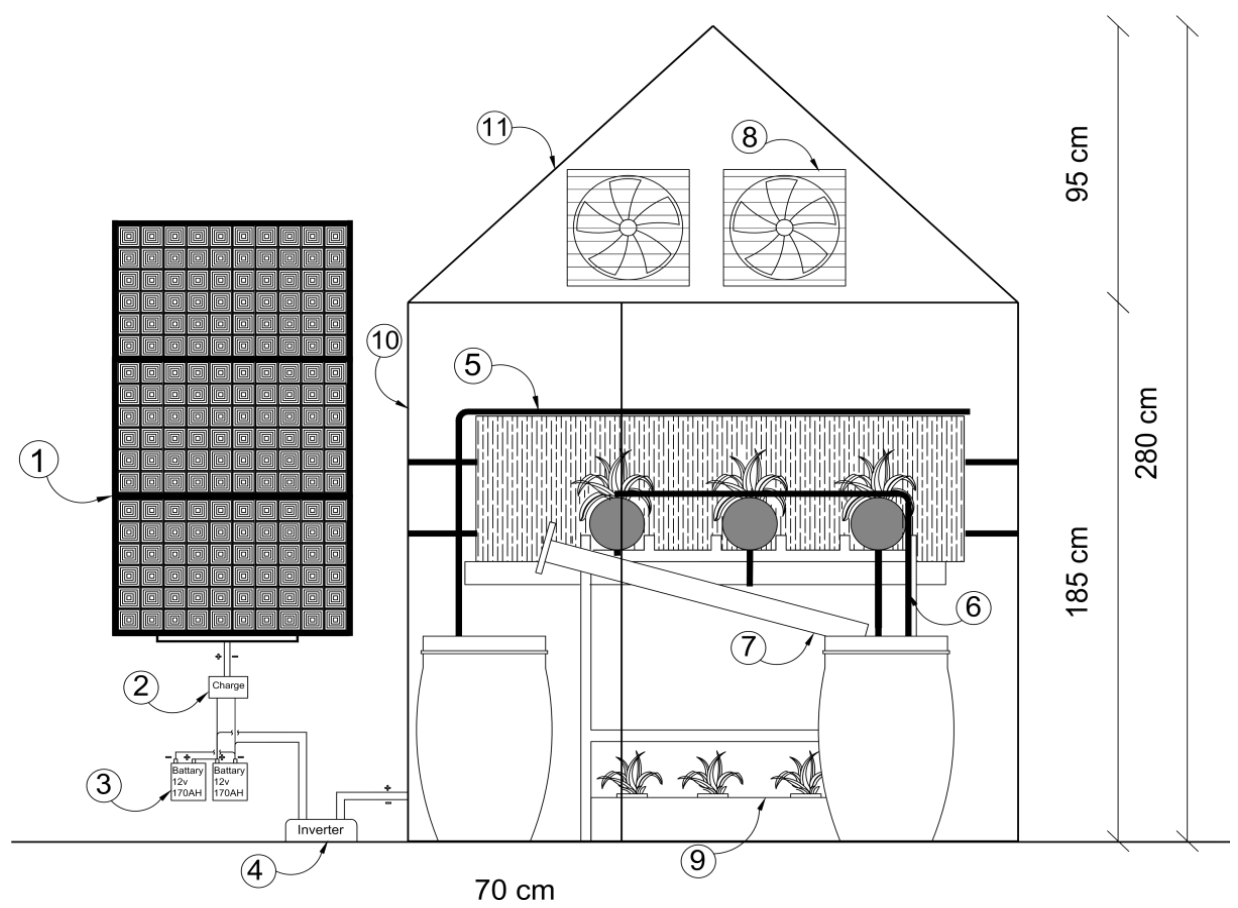

Fig. (1):Schematic diagram showing the basic dimensions and component of the constructed greenhouse.

1) solar cells modules

3) Battery

5) Cooling Pad

7) Hydroponic exchange Unit

9) Deep water culture
2) Charge Controller

4) Inverter

6) Hydroponic feeding unit

8) Cool air fan

10) Gable-even-span greenhouse

11) Polyethylene sheet to cover greenhouse

\section{Instrumentation}

a. Thermocouples (K-type) and a data logger (consort $\mathrm{t} 851,-200{ }^{\circ} \mathrm{C}$ to $1370{ }^{\circ} \mathrm{C}$ range, 16 input channels) were used to measure the following temperatures: the inlet and outlet temperatures of the greenhouse , air in and outside the greenhouse.

b. Electrical thermostats $\left(0-40{ }^{\circ} \mathrm{C}\right.$ range $)$ as shown figure (16) was used to control the water pump operation and Ventilation fans. When the inside temperature of the greenhouse air is upper than $20{ }^{\circ} \mathrm{C}$, the thermostat operates the pump until the air temperature reaches the desired plant temperature.

c. Air Velocity and relative humidity were measured with an analog cup anaometer model 37000-00, cole pormer instrument company, 
Vernon Hill, Illinois 60061-1844, made in USA was used to measure the inlet air velocity in the greenhouse with an accuracy of $0.01 \mathrm{~m} / \mathrm{s}$.

d. Analog PH Meter and Conductivity Meter:

e. Voltage and Current emitted by the three photovoltaic panels was measured with the digital multi meter.

\section{Calculations}

\subsection{Cooling efficiency $(\eta, \%)$}

$$
\boldsymbol{\eta}=\left(\mathbf{T}_{\mathbf{a o}}-\mathbf{T}_{\mathbf{p a d}} \div \mathbf{T}_{\mathbf{a o}}-\mathbf{T}_{\mathbf{a o w}}\right) \times \mathbf{1 0 0}, \boldsymbol{\%}
$$

Where, $\mathrm{T}_{\mathrm{ao}}$, is the outdoor air temperature in ${ }^{\circ} \mathrm{C}, \mathrm{T}_{\mathrm{pad}}$, is the cooled air just leaving the cooling pads in ${ }^{\circ} \mathrm{C}$, and, $\mathrm{T}_{\text {aow }}$, is the wet-bulb air temperature of the outdoor in ${ }^{\circ} \mathrm{C}$.

\subsection{Heat losses from the greenhouse}

\section{a. Heat flow through the polyethylene}

Heat flow through the greenhouse covering materials (walls and roof) during the heating season is represented the greatest losses with respect to the other energy losses from the greenhouse. It is generally related the temperature difference between the inside and outside temperature by the overall heat transfer coefficient as following

$$
Q_{c}=U \times A \times\left(T_{i}-T_{o}\right)
$$

(Ibrahim, 2000 and Abdel-Lattif,

\section{3)}

Where

$\mathrm{Q}_{\mathrm{c}} \quad$ : Heat flow, $\mathrm{J} / \mathrm{s}$; (w)

$\mathrm{U} \quad$ : Overall heat transfer coefficient, $\mathrm{W} /\left(\mathrm{m}^{2} .{ }^{\circ} \mathrm{C}\right)$;

A : : Area of greenhouse wall and roof, $\mathrm{m}^{2}$;

$\mathrm{T}_{\mathrm{i}} \quad$ : Interior ambient air temperature, ${ }^{\circ} \mathrm{C}$;

$\mathrm{T}_{\mathrm{o}} \quad$ : Exterior ambient air temperature, ${ }^{\circ} \mathrm{C}$.

\section{b. Energy loss via ventilation}

Heat loss via ventilation $\left(Q_{\mathrm{v}}\right)$ is approximated as follows (Ibrahim, 2000)

$$
\mathrm{Q}_{\mathrm{v}}=\mathrm{Q}_{\mathrm{sv}}+\mathrm{Q}_{\mathrm{lv}}
$$

Where

$\mathrm{Q}_{\mathrm{sv}}$ is the sensible heat losses via ventilation;

$\mathrm{Q}_{\mathrm{lv}}$ is latent heat losses via ventilation;

$\mathrm{Q}_{\mathrm{sv}}=\dot{m} \times c p \times\left(T_{\text {in }}-T_{o}\right), \mathrm{J} / \mathrm{s}$ (Abdel-Lattif, 1993).

$Q_{l v}=E \times F \times Q_{i}=E \times F \times \tau I A_{f}$ 
Where

$\tau \quad$ Transmittance of greenhouse covering (assumed 88\%);

I Total solar radiation outside the greenhouse on horizontal surface $\quad\left(\mathrm{W} / \mathrm{m}^{2}\right)$, it was obtained from the weather station of the arid land and agricultural research and services center Faculty of Agriculture,Ain Shams University. ;

$A_{f} \quad$ Floor area of the greenhouse, $\left(\mathrm{m}^{2}\right)$;

$\dot{m} \quad$ Mass flow rate of air $\mathrm{kg} / \mathrm{s}=\mathrm{V} \times \rho / 3600$, (AbdelLattif, 1993);

Where

$\mathrm{V}=$ greenhouse volume $\mathrm{x}$ air exchange rate per hour,$\left(\mathrm{m}^{3} / \mathrm{h}\right)$;

$\rho=\operatorname{air} \operatorname{density}\left(=1.2 \mathrm{~kg} / \mathrm{m}^{3}\right)$;

$\mathrm{C}_{\mathrm{p}}=\quad$ Air specific heat $1007 \mathrm{~J} / \mathrm{kg} .{ }^{\circ} \mathrm{C}$;

$\mathrm{E}=$ Floor use factor-ratio of ground covered by plants to total ground area, (assumed 0.4 );

$\mathrm{F}=$ Evapotranspiration to internal solar radiation .

\section{c. Total losses}

\section{3-3- Mechanical ventilation}

$$
\mathrm{Q}_{\text {loss }}=\mathrm{Q}_{\mathrm{c}}+\mathrm{Q}_{\mathrm{v}}
$$

\section{a. Determining ventilation volume rate}

The ventilation volume rate may be calculated by the following equation

$$
\text { Air volume flow rate }\left(\mathrm{m}^{3} / \mathrm{h}\right)=\mathrm{V}_{\text {gh }} \mathrm{x} \text { AR }
$$

Where

Vgr : Greenhouse volume, $\mathrm{m}^{3}$;

AR : Air exchange rate per hour $1 / \mathrm{min}$

In Summer AR = $2 \quad 1 / \mathrm{min}$

(Buffington et al., 2002).

\section{b. Size of the intake vent}

The following equation is used to determine the area of the air inlet

Size of the intake vent $=\frac{\text { Air volumetric flow rate }\left(\mathrm{m}^{3} / \mathrm{h}\right)}{\text { Maximum air speed allowed }(\mathrm{m} / \mathrm{h})}$

Since air speed influences many factors that affect plant growth, such as transpiration, evaporation, leaf temperature, and carbon dioxide 
availability, the maximum air speed allowed through the vent was used to be $1.27 \mathrm{~m} / \mathrm{s}$ (Abdel-Lattif, 1993).

\section{c. Natural ventilation}

Natural ventilation depends upon the ventilation opening area's and positions, to achieve the optimum air exchange in the greenhouse, the lateral wall opening and roof holes in the range (15-30)\% of the floor area of the greenhouse (Ibrahim, 2000).

\subsection{Water consumption.}

The water consumption average for each plant during ten days ( liter/day) for each scale. The water consumption was calculated by the shortage difference in nutrient solution volume between the two tanks. Also, the Water-Use Efficiency (WUE) was calculated for each plant, as mentioned by (Awady et al.,2007).

\section{a. Water use efficiency (WUE)}

Knowledge of water-use efficiency (WUE) is essential in crops management mainly in arid and semiarid regions where water resources are scarce for irrigation. Bar-Yosef, 2008). The water use efficiency calculated according to Jensen (1983) as follows:

$$
\mathrm{WUE}=\mathrm{Y} / \mathrm{W}
$$

Where;

WUE: water use efficiency, $\mathrm{kg} / \mathrm{m}^{3}$ water.

Y: total fresh mass, $\mathrm{kg}$.

$\mathrm{W}$ : total applied irrigation water, $\mathrm{m}^{3}$.

\subsection{Methodology used in the determination of the power and} efficiency of the system:

Measurements were performed in order to evaluate the performance of Photovoltaic solar system and PV efficiency under conditions of different parameters affecting the performance. In order to study the power conversion from solar radiation, the following equations were used Hamza and Taha, (1995).

\section{a. The Input Power:}

The incident solar radiation to the PV array gives the input power (Pi) to the system:

$$
\mathrm{Pi}=\mathrm{G} x \mathrm{~A} \quad(\mathrm{~W})
$$

Where: $\mathrm{G}=$ solar radiation $\left(\mathrm{W} / \mathrm{m}^{2}\right)$ and $\mathrm{A}=$ effective module cell area $\left(\mathrm{m}^{2}\right)$. 


\section{b. PV Array Output:}

The d.c. output power (Po) from the PV array is given by:

$$
\mathrm{Po}=V x I \quad(\mathrm{~W})
$$

Where $\mathrm{V}=$ d.c. operating voltage $(\mathrm{V}) ; \mathrm{I}=$ d.c. operating current $(\mathrm{A})$.

\section{c. Array efficiency:}

Array efficiency (Ea) is the measure of how efficient the PV array is in converting sunlight to electricity:

$$
\mathrm{Ea}=\mathrm{Po} / \mathrm{Pi} \times 100 \%
$$

\subsection{Cost analysis}

The hourly cost was included fixed costs and operating costs. The parameters which are considered while cost evaluation are presented

\section{Fixed costs:}

1-Depreciation, $($ L.E/year $)=\frac{\text { Originalcost }- \text { Salvagevalue }}{\text { Mechanicallife }}$

Salvage value is $10 \%$ of original cost

2- Interest, $($ L.E/year $)=$ Interest rate $\times \frac{\text { originalcost }+ \text { Salvagevalue }}{2}$

Interest rate is $12 \%$

3- Shelter, taxes and insurance, $($ L.E/year) $=4.5 \% \times$ originalcost

Total fixed cost, $(\mathrm{L} . \mathrm{E} / \mathrm{h})=$

Depreciation+Interest + Shelter,taxesandinsurance

$$
\text { hourofuseperyear }
$$

\section{Operating costs:}

1 - Repair and maintenance, $(\mathrm{L} . \mathrm{E} / \mathrm{h})=\frac{100 \% \text { Deprecicationcost }}{\text { hourofuseperyear }}$

2- Labour, (L.E/h).

3- Electricity, (L.E/h).

Total operating cost, $(\mathrm{L} . \mathrm{E} / \mathrm{h})=$ Repair and maintenance + Labour + Electricity

Total costs, $(\mathrm{L} . \mathrm{E} / \mathrm{h})=$ Fixed costs + Operating costs

$\left(\right.$ Total costs per productivity, $\left.(\mathrm{L} . \mathrm{E} / \mathrm{Kg})=\frac{\text { Totalcosts },(\mathrm{L} . \mathrm{E} / \mathrm{h})}{\text { Productivity },(\mathrm{Kg} / \mathrm{h})}\right)$

\section{RESULTS AND DISCUSSION}

\section{Hourly variation of temperatures}

Figs. (2) Illustrates the average hourly temperature variation of the ambient, inside the treatment and control greenhouses. The results show that during autumn season the temperatures of the air gradually increased with the time, until 2:00 pm, then it reduced towards the evening. The 
control greenhouse temperature was higher than the ambient one Because of the polyethylene cover that raises the temperature inside the greenhouse from outside; during day of course the treatment greenhouse temperature was lowest due to using cooling system.
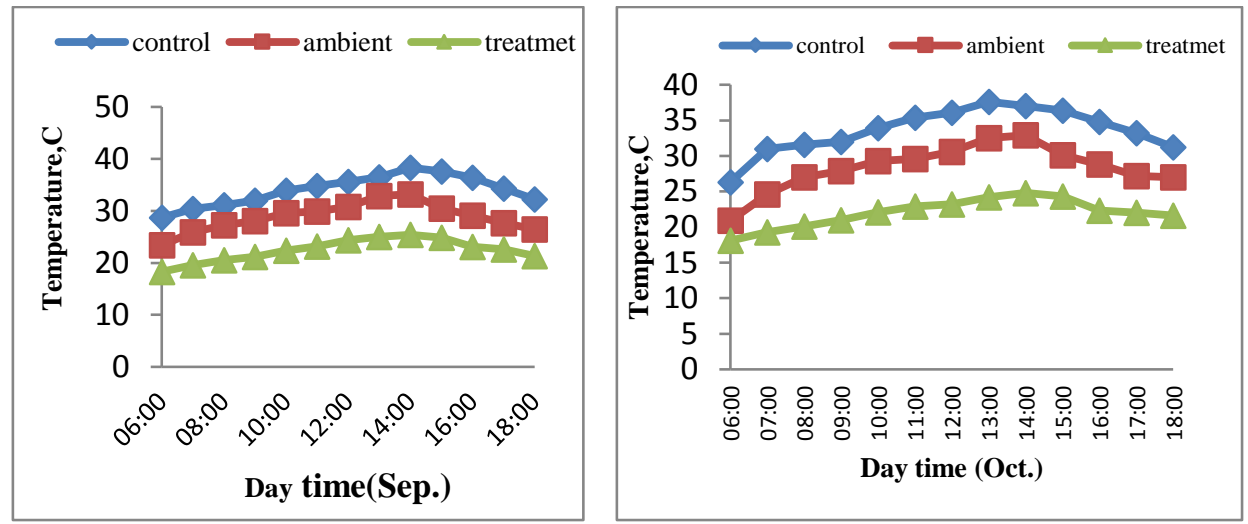

Figs. (2): The average air temperatures outside and inside the treatment and control greenhouses vs. time during autumn season.

Figs. (3) Show that the temperature inside greenhouses approximately equals' with some small difference but it was notes that the temperature beside the pad cooling continuously was lower than the center and exist. As a result of the presence of cooling pads saturated with water, which makes the degree of heat at the pads less and the further away from these pads the higher the temperature air.

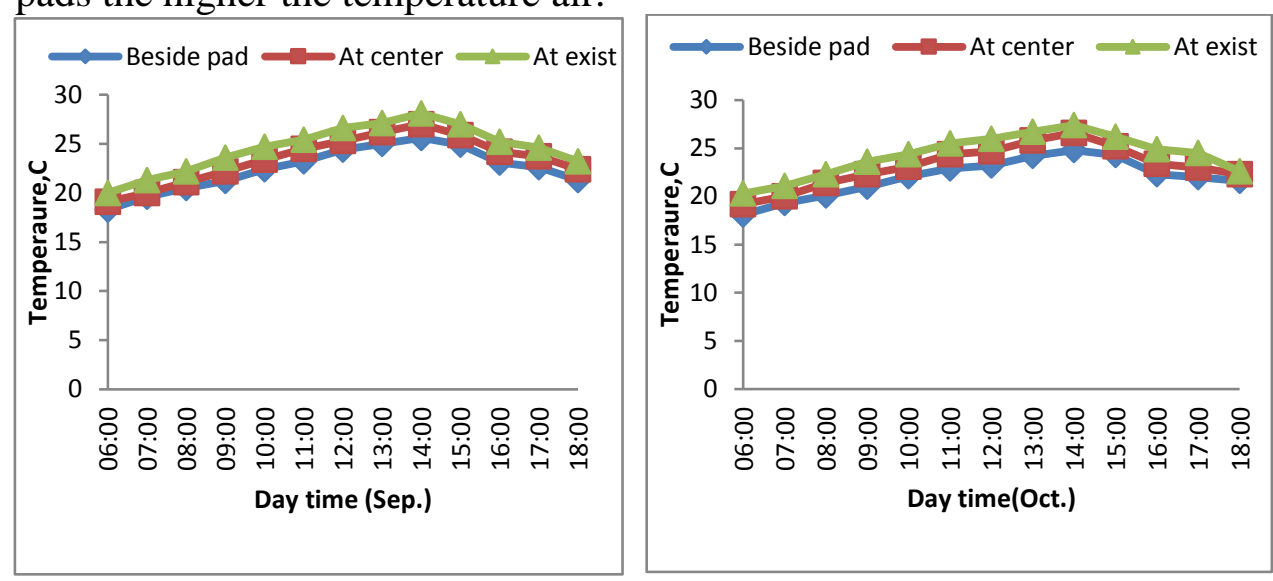

Figs. (3): Average air temperatures between beside pad, at center and at exist treatment greenhouses vs. time. 


\section{Relative humidity}

Figs; (4) discuss the relationship between the hourly relative humidity variations of the greenhouse during autumn season. It is clear that the relative humidity inside the greenhouses gradually decreased with time of the day at 6:00 am hour it reached to the minimum all measurements at 4:00 pm then increased gradually at $6: 00 \mathrm{pm}$. These results could be attributed to the fact that the level of the inside relative humidity is accompanied by the level of temperatures inside the greenhouses. The results have also show that the relative humidity of the treatment greenhouse is higher than the ambient air humidity and there is slight increase in the relative humidity of the control.
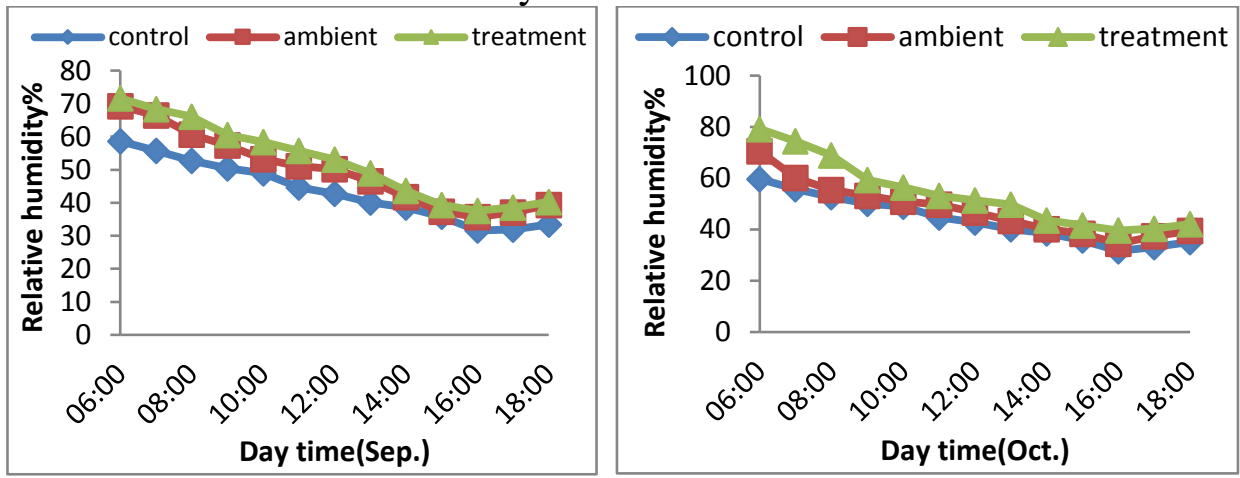

Figs. (4): Average air relative humidity outside and inside the treatment and control greenhouses vs. time.

Figs. (5) show that the relative humidity inside greenhouses approximately equals with some small different but notes that the relative humidity beside the pad cooling continuously was lower than the center and existent control greenhouses vs. time .

\section{Cooling efficiency}

The hourly cooling efficiency of pad cooling is illustrated in fig. (6). The recorded results indicated that the cooling efficiency was lowest in the morning (starting the system), because the system is not yet stabilized and the greenhouse effect (thermal effect) takes place. Also, the cooling efficiency values were lowest in the morning when relative humidity levels were high. Since the wet bulb depression was the highest at 12:00 to $14: 00 \mathrm{pm}$ in the afternoon, when the dry-bulb temperature was normally at his peak, the highest efficiency of the evaporative cooling 
was achieved. Notes the highest efficiency of cooling system at noon but it lowest at the morning and night,
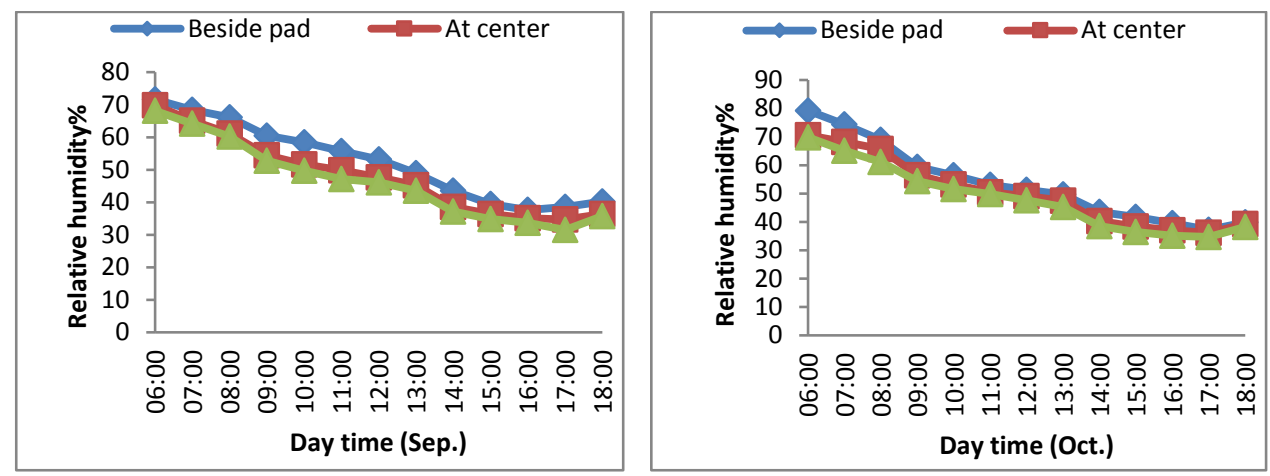

Figs. (5): Average air relative humidity between beside pad, at center and at exist treatment greenhouses vs. time.

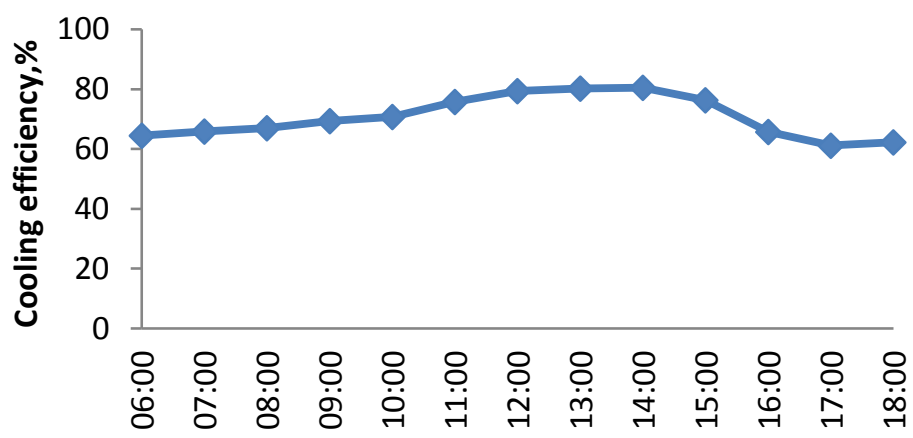

Day time

Fig. (6): Relationship between day time and cooling efficiency.

\section{Heat losses through the greenhouse}

Fig. (7) are show that the results of the mean components $\left(Q_{v}, Q_{c}\right)$ and $\mathrm{Q}_{\text {total }}$ of the greenhouse energy loses (treatment greenhouse) during the day time .It can be noticed that, energy lost via ventilation increasing gradually from $6 a \mathrm{~m}$ to $1 \mathrm{pm}$ and decreasing after $1 \mathrm{pm}$ to $6 \mathrm{pm}$ but the heat flow through the polyethylene was approximately stabile from 7 am to $10 \mathrm{am}$ and began to increase gradually after 10 am to $1 \mathrm{pm}$, then decreasing after $1 \mathrm{pm}$ to $6 \mathrm{pm}$. Also, it be noticed that the greatest total losses of the energy from the greenhouses were at about $1.0 \mathrm{pm}$ the 
reason of that is the air temperature difference between outside and inside greenhouse were huge.

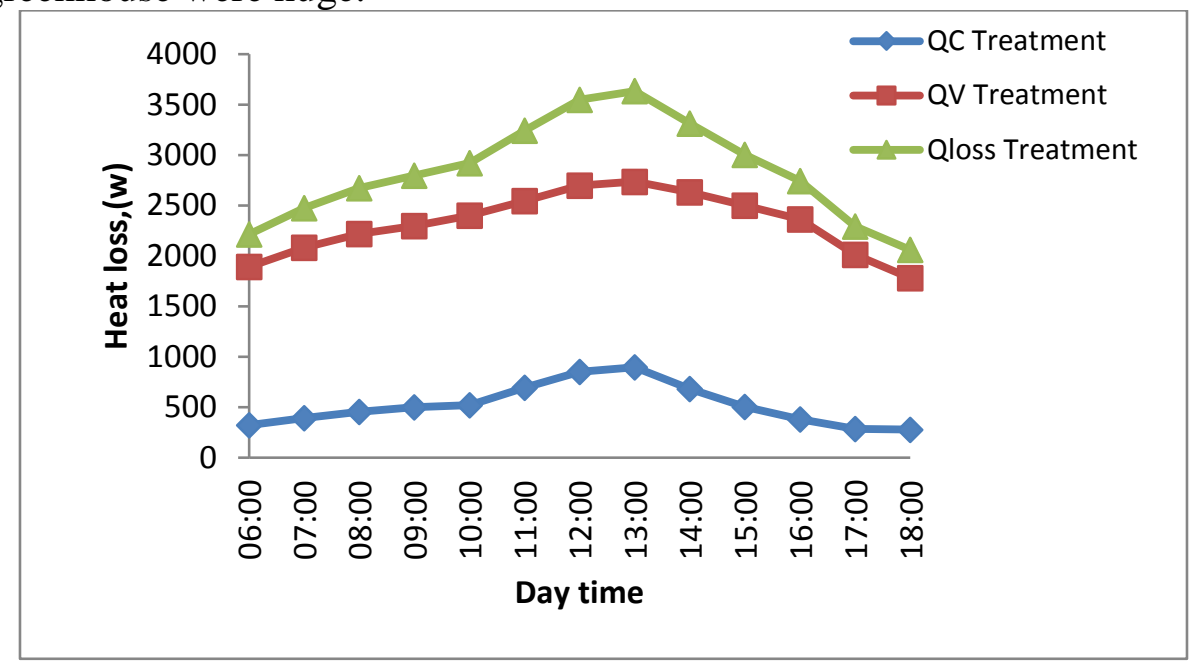

Fig. (7): Heat loss through the greenhouse during autumn season.

\section{Effect of cooling and ventilation on plant growth of lettuce and mint.}

Figs. (8), (9), (10),(11)and (12) show the effect of cooling and mechanical ventilation on the height of plant, length of total root, Nutrient solution consumption and lettuce and mint production per plant during summer season of 2018. The obtained data show significant increase in all the above parameters in case of the treatment greenhouse as compared with the control greenhouse. Such increases were $15.12 \%, 19.21 \%, 5.16 \%$ and $52.88 \%$, respectively for lettuce, but mint increases were $17.34 \%, 22.85 \%, 3.16 \%, 49.91 \%$ respectively, at the end of the growth season, but water consumption use inside the treatment greenhouse was lowest because it ad jested at the optimum temperature by using cooling system.

These increases may be due to control the interior climate (cool and $\mathrm{RH}$ ) for plant growth under environmentally appropriate conditions, which help for (a) increasing the rate of nutrient absorption due to maintaining the optimum growth temperature; (b) forming a large number of leaves, which are necessary for photosynthesis process; and (c) increasing diameter and height of stem and consequently increasing the lettuce and mint production. 

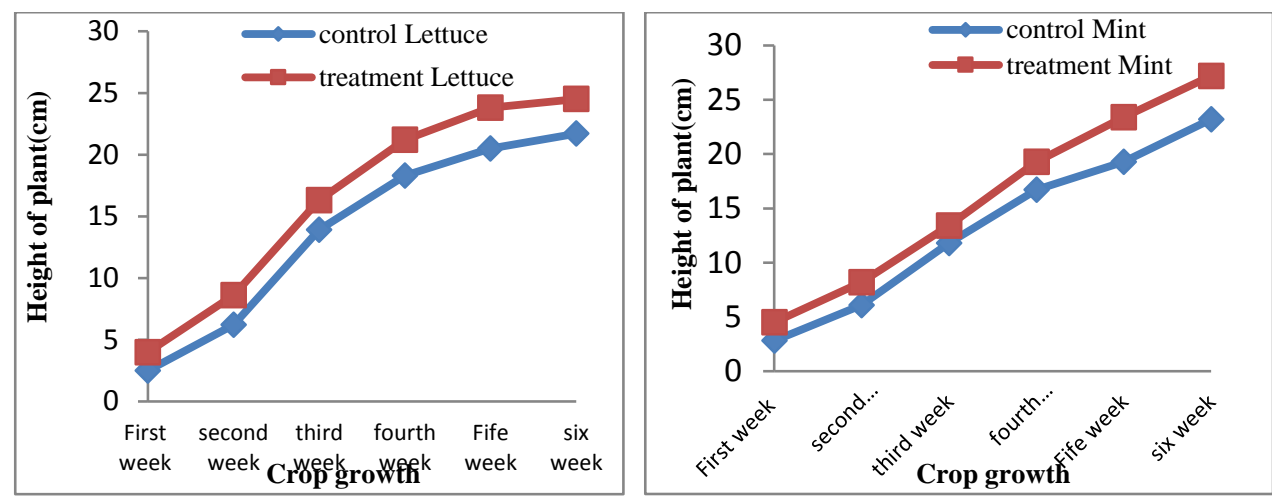

Figs. (8): Development plants through growth stage for lettuce and Mint during autumn season.
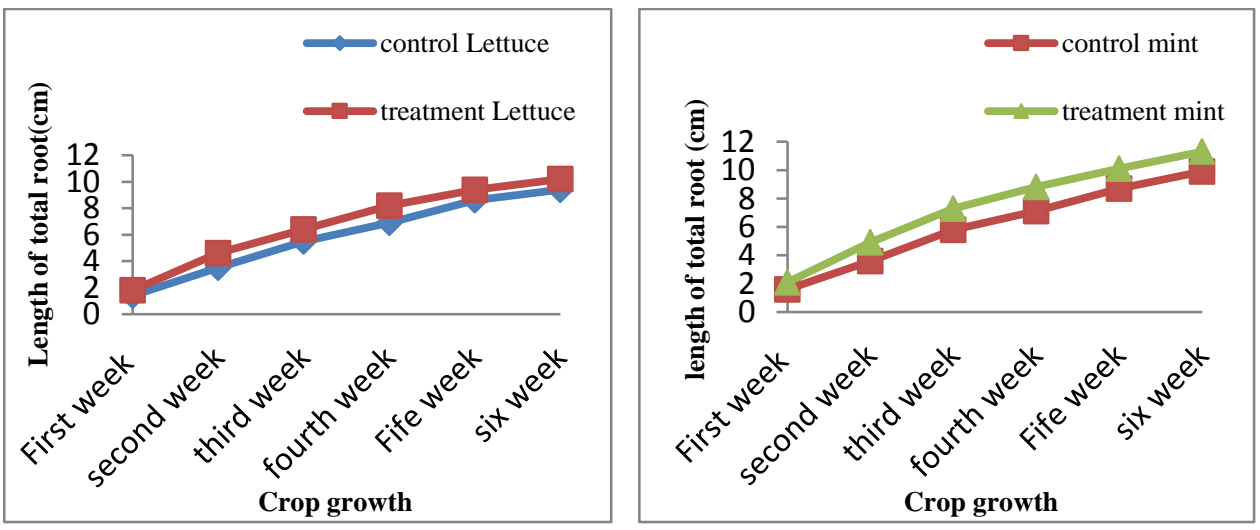

Figs. (9): Length of total root through growth stage for lettuce and mint during autumn season.
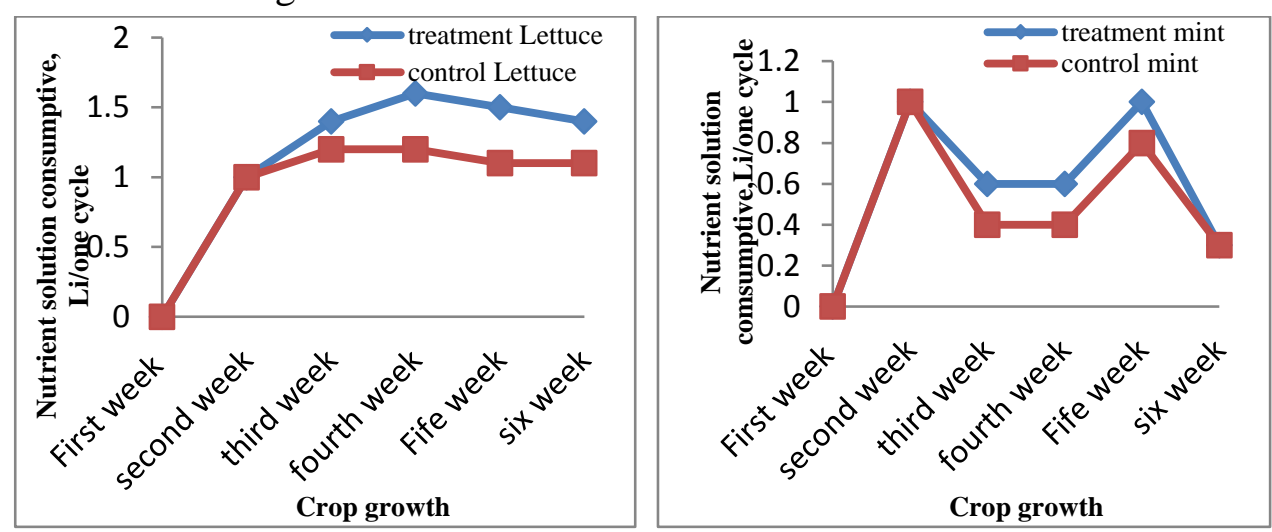

Figs. (10): Nutrient solution consumptive use for mint through growth stage during autumn season. 


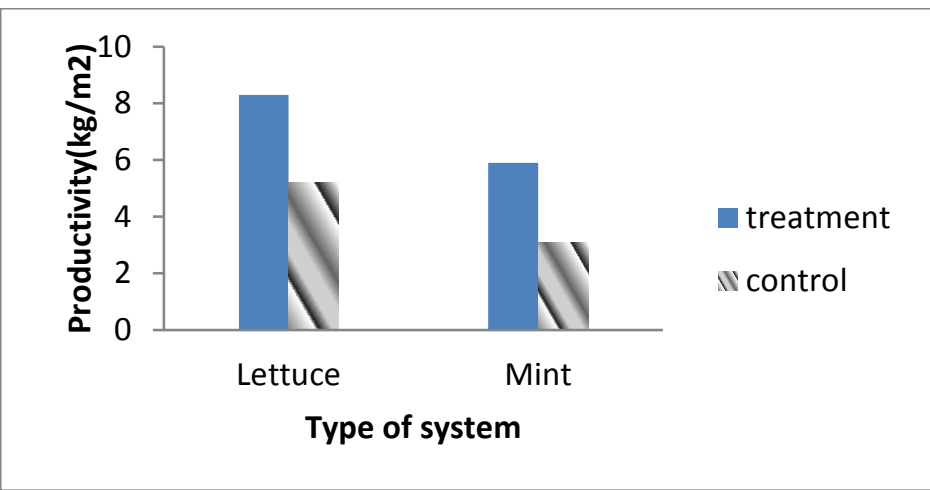

Fig. (11): The average production per plant of the treatment and control greenhouses at the end of growing during autumn season for lettuce and mint.
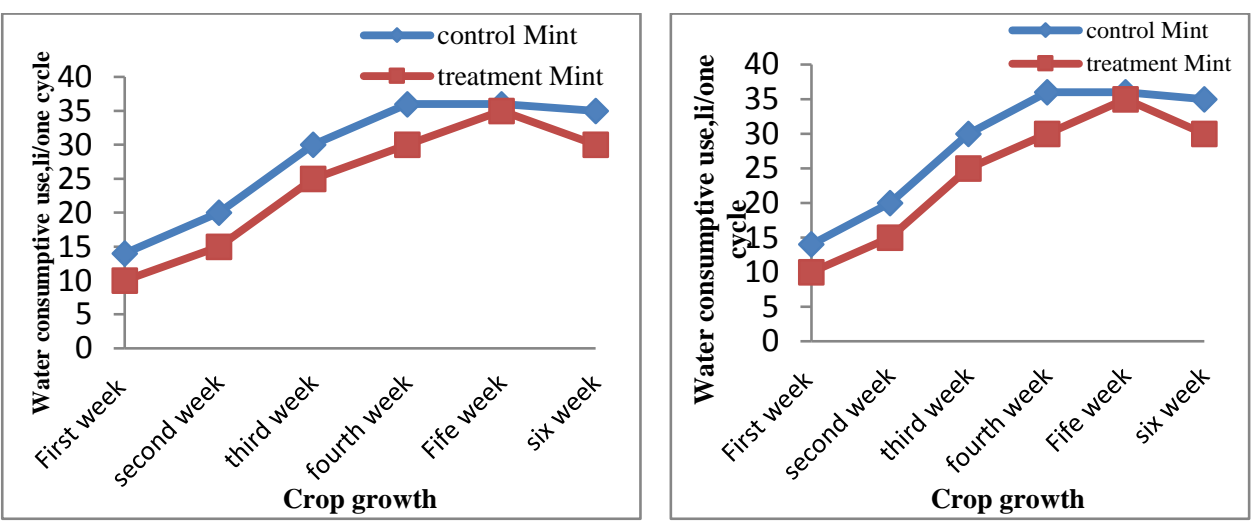

Figs. (12): Water consumptive use for lettuce through growth stage during autumn season.

\section{Solar radiation and electric power}

\section{a. Solar radiation}

Fig. (13) Shows that the hourly solar radiation flux values inside and outside the greenhouse at all the experiment. The values of solar radiation varied from hour to hour due to climate conditions, variation in solar altitude angle from early morning to late afternoon and solar incident angle. It shows that the solar radiations were race from 8:00 am until at the maximum point at $12: 00 \mathrm{pm}$ then it reduces to the optimum at $6: 00$ pm. 


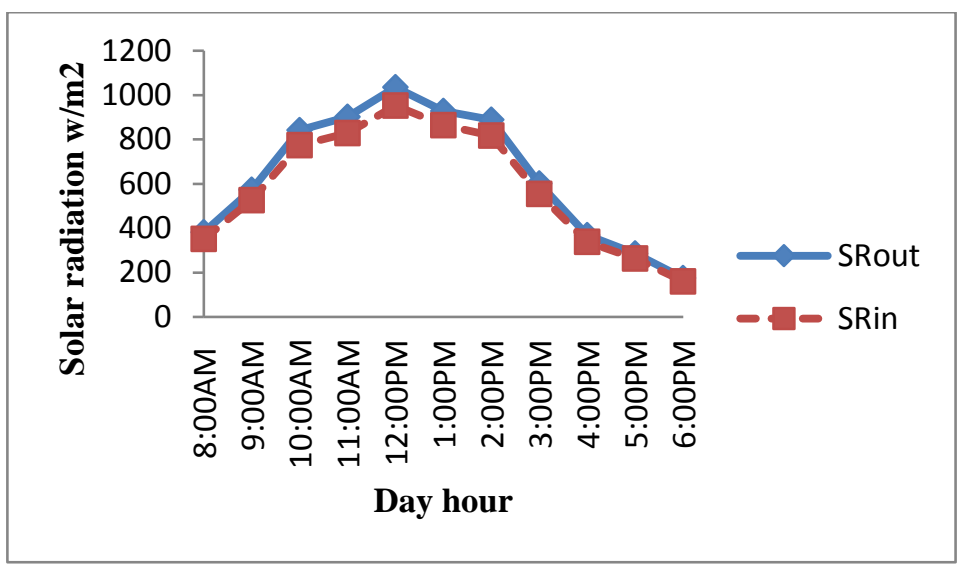

Fig. (13): Average solar radiation of daily hourly between inside and outside greenhouse during autumn season.

\section{b. Input power}

Fig. (14) Show that average input power obtained during the experiment period during autumn season. Show that the high-test input power for the autumn and winter season almost at 12:00 pm but the low input power always in the morning and night.

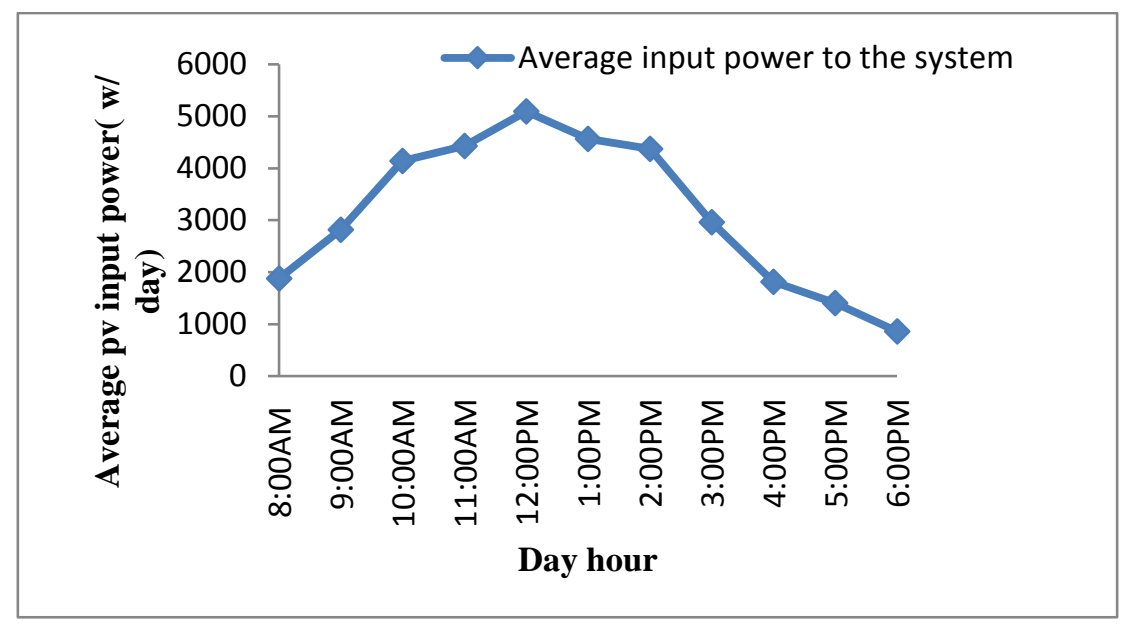

Fig. (14): Average input power to the system (W/day).

\section{c. PV array output}

\section{a. Generated electric power}

Output power of the PV array was measured every hour during the experiment period. The short circuit current and short circuit voltage of the PV array have been measured directly from the PV panels using two 
multi-meters; the first millimeter was used for measuring the current where the second was used to measure the voltage.

Fig. (15) Show hourly average output power obtained during the experiment period with the incident hourly average solar radiation.

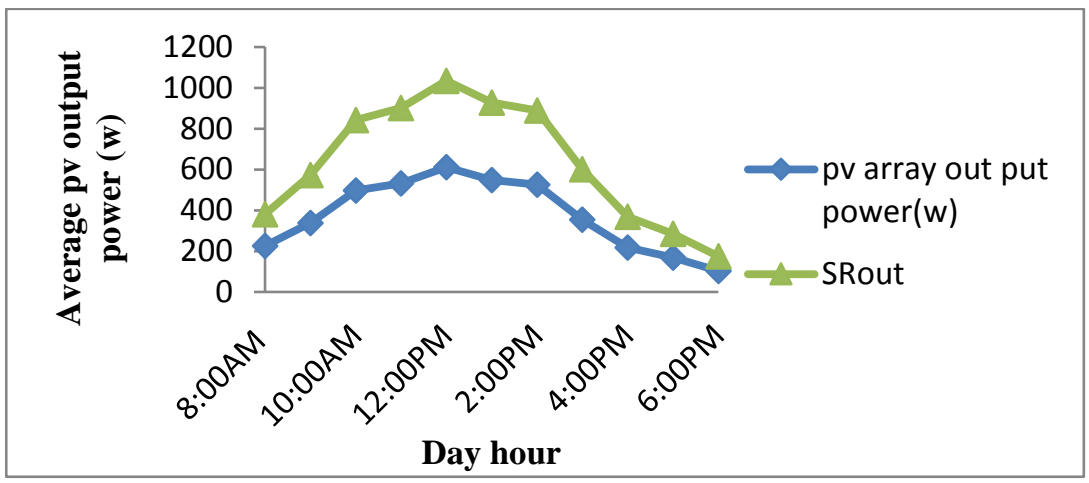

Fig. (15): Average PVarray output power (W) of daily hourly during autumn season.

Fig. (16) Show that the relationship between the solar radiation and PV output power for autumn and winter seasons. Seriously relationship the results show that output power increasing gradually with increase solar radiation intensity, and notes that the maximum solar radiation at the maximum PV output power.

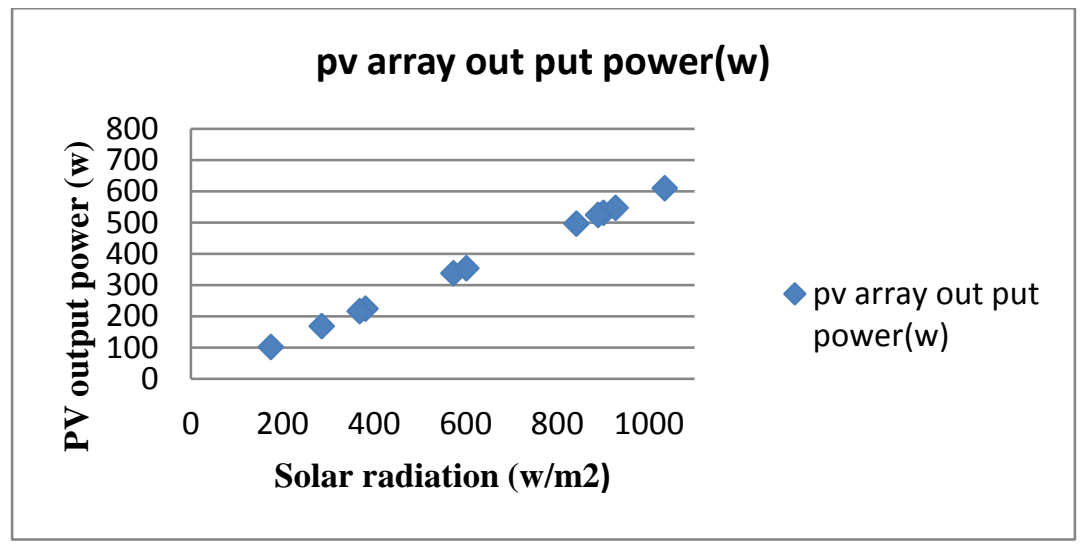

Fig. (16): Daily measured output power as a function of average solar radiation intensity during autumn season.

\section{Cost analysis for one $\mathbf{m}^{\mathbf{2}}$ of greenhouse was:}

1. Prototype included (structure spolyethylene plastic, PVC pipe, submersible pump, fans, solar cell, charge controller, battery, 
inverter, nutrient solution, seedlings, cup of seedlings, tanks, timer, pipe of $\mathrm{Gr}$ and frame).

2. The total cost for one $\mathrm{m}^{2}$ of greenhouse treatment was about 274.15 L.E $/ \mathrm{m}^{2}$. Product $150 \mathrm{~kg} /$ year fresh green lettuce in the area of $1 \mathrm{~m}^{2}$. The kilogram of fresh lettuce water worth 10 L.E, so the net profit was 1225.85 L.E/year.

$3.56 \mathrm{~kg} /$ year of fresh green mint selected in an area of $1 \mathrm{~m}^{2}$. The kilogram of fresh mint water worth of 8 L.E, so the net profit was 173.85 L.E/year.

4. The total cost for one $\mathrm{m}^{2}$ of greenhouse control was about 134.27 L.E $/ \mathrm{m}^{2}$.

\section{CONCLUSION}

According to the experimental results,

1. During summer season the temperatures of the air gradually increased with the time, then it reduced towards the evening. The control greenhouse temperature was higher than the ambient one; during day night of course the treatment greenhouse temperature was lowest because using cooling system.

2. The relative humidity of the treatment greenhouse is higher than the ambient air humidity and there is slight increase in the relative humidity of the control .Also, during winter season as the same as during the summer season.

3. The cooling efficiency was low in the morning is about $64.5 \%$ but at none is about $79.37 \%$ then it reduced gradually to $62.2 \%$ at night.

4. The greatest total losses of the energy from the greenhouses were at about 1:00 pm the reason of that is the air temperature difference between outside and inside greenhouse was maximum.

5. The total root length inside the treatment greenhouse was the highest than the control greenhouse because it adjusted at the optimum temperature by using cooling control system. The water consumption use inside the treatment greenhouse was lowest because it adjusted at the optimum temperature by using cooling system. The Nutrient solution consumption inside the treatment greenhouse was the highest because it adjusted at the optimum temperature by using cooling system. 
6. The high input power for the summer season almost at 12:00 pm but the low input power always in the morning and night. the output power increase gradualy from 8:00 am in the morning to arrive at the maximum amount at $12: 00 \mathrm{pm}$ is about $611.102 \mathrm{~W}$ then if reduce gradualy until arrive to the minimum at 6:00 $\mathrm{pm}$ summer seasones.

\section{REFERENCES}

Aldrish, A.R.andBartok.w.J.(1994).greenhouse engineering. NRASE33-3 $3^{\text {rd }}$ edition.

Arbel A, Barak M, Shklyar A (2003). Combination of forced ventilation and fogging systems forcooling greenhouses.BiosyEng 84:45-55.

Awady, M.N., Hegazy, M.M., Abd El-salam, M.F.M. and Tawfiq,F.D., (2007).Utilitzation of Non-Traditional Energy in Water Culture for Remote Areas, Misr Journal of Agricultural Engineering, Vol.24.No.1

Bar-Yosef, B., 2008. Fertigation management and crops response to solution recycling in semi-closed greenhouses. In: Raviv, M.,Lieth, H.(Eds), Soilless Culture, Theory and practices. Elsevier, Amsterdam,pp.341-424.

Buffington, D.E.; Bucklin, D.A.; Henley, R.W., and Mc Connell, D.B. (2002).Fansforgreenhouses, institute of food and agriculture science, universityofFlorida AE-11.

Gao, Z. (2012)."Dehumidification of greenhouse in cold regions".Thesis, degree of, Sc, Uni. of Saskatchewan.

Santosh, D.T., Tiwari, K.N., Singh, V.K., Raja, A., Reddy, G., (2017). Micro climate controlin greenhouse. Int. J. Curr. Microbiol. Appl.Sci6,17301742.http://dx.doi.org/10.20546/ijcmas.2017.603.19 9.

Abu-Hamdeh, N.H., Almitani, K.H., (2016). Solar liquid desiccant regeneration and nano-fluids in evaporative cooling for greenhouse food production in Saudi Arabia. Sol.Energy 134, 202210.http://dx.doi.org/10.1016/j.solener.2016.04.048.

FAOSTAT[WWWDocument],(2014). <http://www.fao.org/faostat/en/\#d ata/QC $>$ (accessed 21.05.17).

HAMZA A.A. and TAHA, A.( 1995).Performance of submersible solar pumping system under conditions in Sudan. 
Jensen,M.E.,(1983),Design and operation of farm irrigation systems. Amer. Soc. Agric. Eng. Michigan.USA P.827.

Kumar, K. S., K. N. Tiwari, and M. K. Jha. (2009). Design and technology for greenhouse cooling in tropical and subtropical regions: A review. Energy and Buildings, 41 (12): 1269-1275.

Marcel Fuchs, Ehud Dayan, Eugene Presnov. (2006).'Evaporative cooling of a ventilated greenhouse rose crop", J. Agricultural and Forest Meteorology,issue138,pp203-215.

المراجع العربية

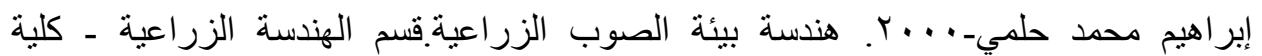
الزر اعية - جامعة الإسكندرية.

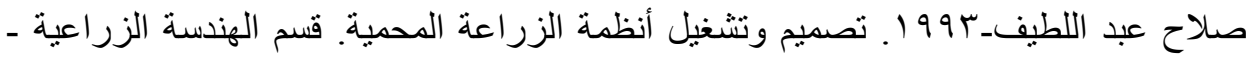
كلية العلوم الزر اعية و الاغذية - جامعة الملك فيصل.

\section{الملخص العزبي \\ إستخدام الطاقة الشمسية إلماية \\ لتشغيل نظام تبريد للزراعة المائية فى الصوب الزئة الزباعية}

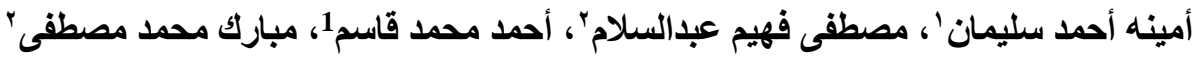

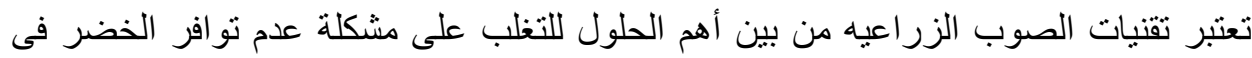

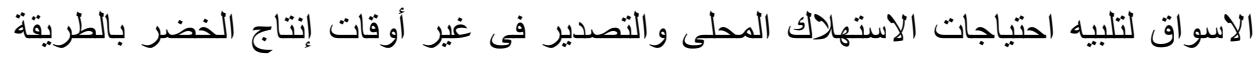

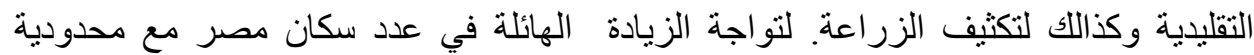

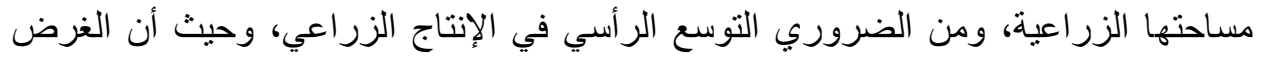

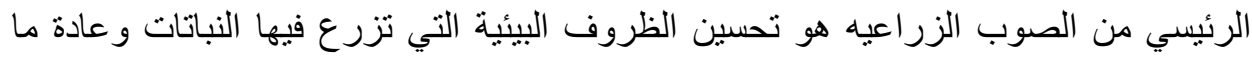
تكون الصوب مزودة ببعض اجهزه التحكم البيئي مثل أنظمة التبريد و التهوية و التنفئة حيث يمكن

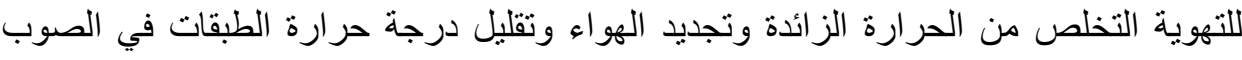
خلال فصل الصيف في مصروحيث أنه التهوية وحدها لا تكفي للحفاظ على درجة الحرارة

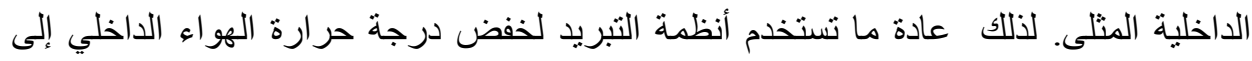

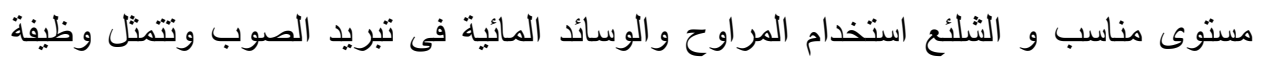

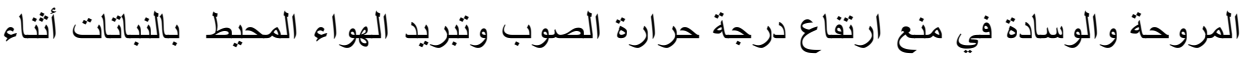

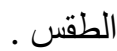

'معهل بحوث الهندسة الزراعية، مركز البحوث الزراعية، الاقى- جيزة- مصر.

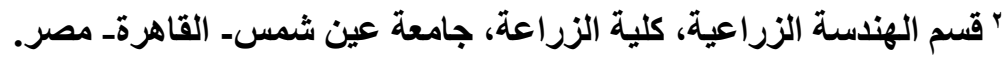




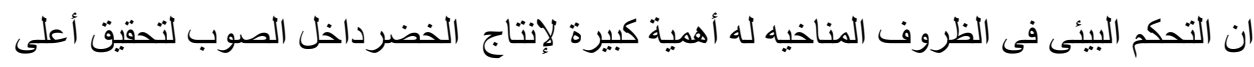
انتاجيه بأقل تكلفة وبأفضل جودة و التي يحتاجها السوق و المستهلك طو ال العام ولذلك تعد درجة الذانة

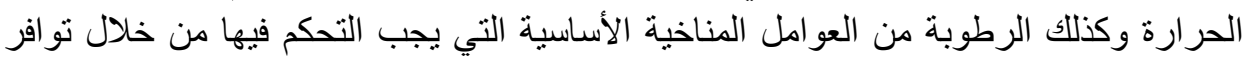
نظامي التبريدو التهوية.

ا ـ الهدف الرئيسي من هذه الدر اسه هو إدخال نظام مقترح لتبريد الصوب و الذي بستخدم نظام

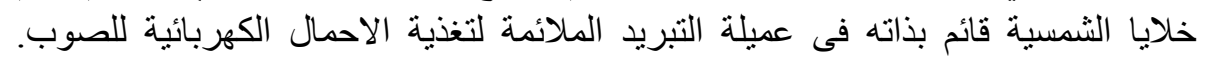

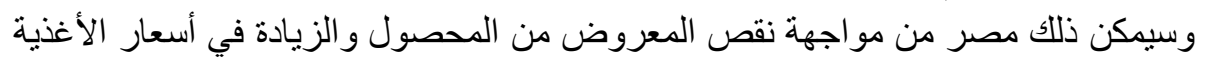

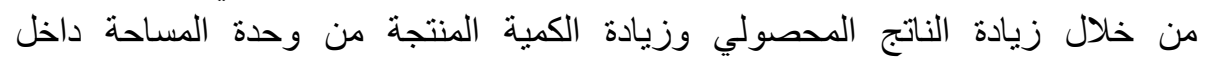
الصوبةوبالتالى يهدف البحث إلى إنشاء وتطوير واختبارصوبة تجريبية مزودة بنظام للتحكم

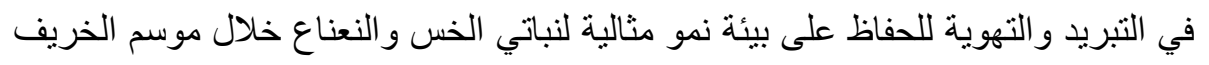

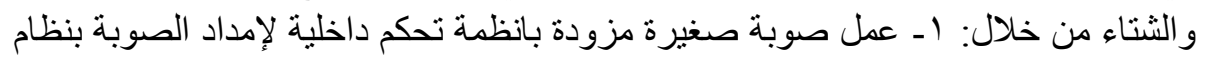

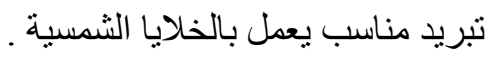

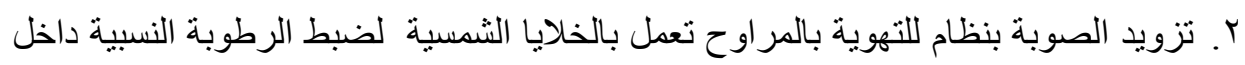
الصوبة. ب. إمداد النظام المصمم بإجهزة قياس كلا من درجات الحرارة والرطوبة النسبية عن طريق وضع ثرموستات وحساس للرطوبة لتوفير الظروف البيئية المناسبة للنبات داخل الصوبة.

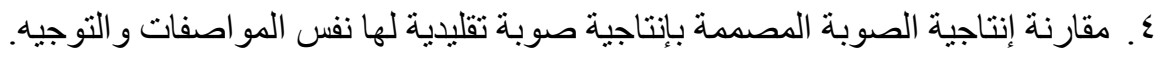

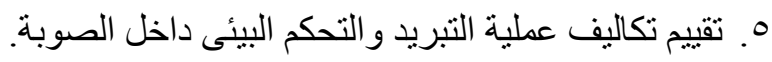

ويمكن تلخيص النتائج فيما يلي:-

- إنخفاض درجة الحرارة الداخلية للصوبة المصممة مقارنة بدرجة الحرارة الحمارة الخارجية

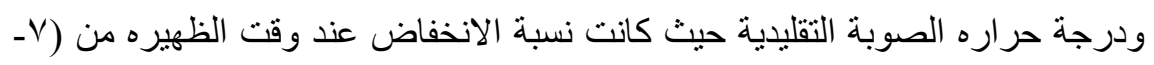

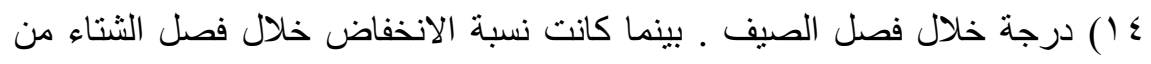

(r.-1·)

- زيادة الرطوبة النسبية للهو اء الداخلى للصوبة المصممة خلال النهار و إنخفاضها أثناء

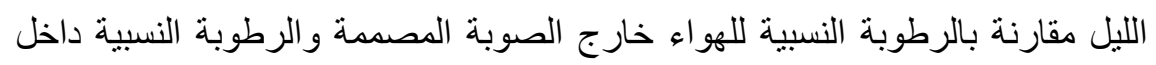

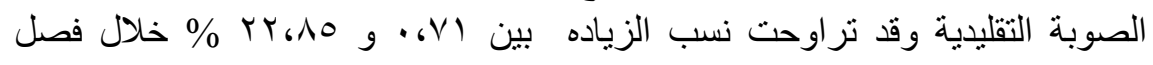

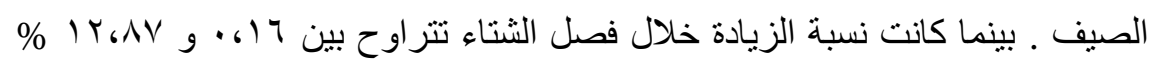

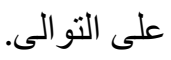
- إنخفاض كل من كمية الحر ارة المكتسبة من الاشعاع الشمسي ، وكمية الحر ارة المفقودة

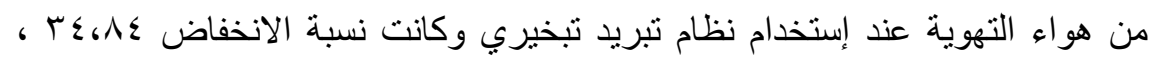

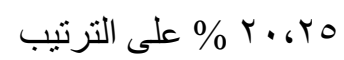

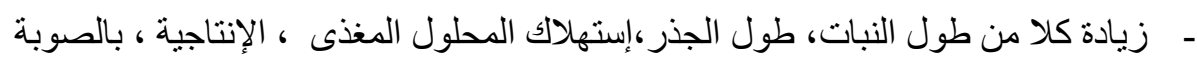

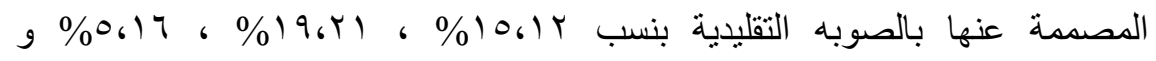

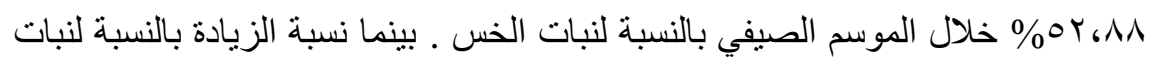




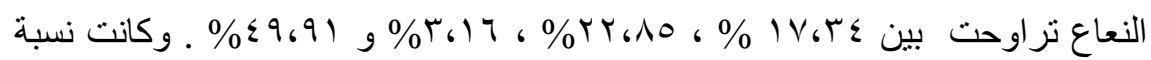

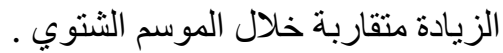

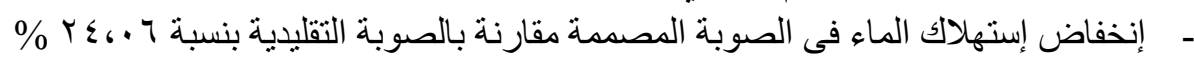

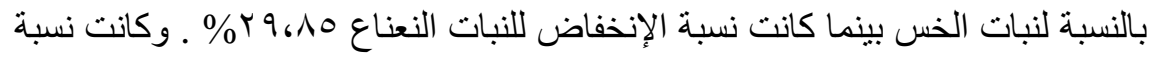
الإنخفاض منقاربة خلال الموسم الثنتوي

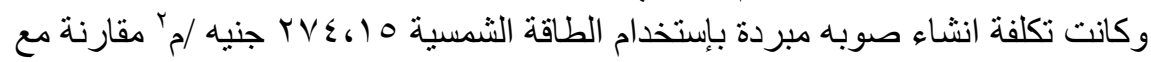

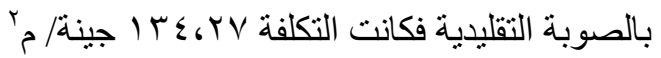

طبقا للنتائج السابقة يوصي البحث بإنة على الرغم من إرتفاع تكلفة الصوبة المصممة المبردة

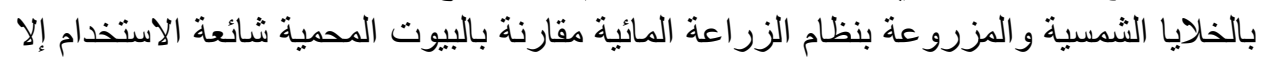
أنه يزيد من التحكم فى المناخ الداخلي للبيت المحمي بدرجة كبيرة كما أنه أدى إلي زياده الكمية

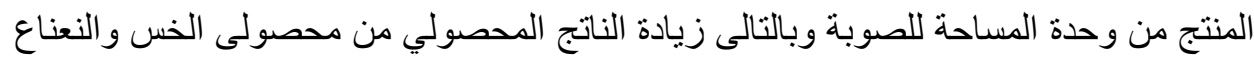

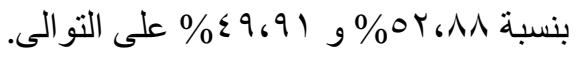

الكلمات الدالة: الصوب ، تبريب تبخيري ، مروحه ووساده ، تهويه ، رطوبه نسبيه ، خلايا شمسبه،زراعه مائبة. 